\author{
Kamila Rezmer-Płotka \\ Nicolaus Copernicus University (Poland)
}

\title{
Activities of the Catholic Church in Poland Against Pedophilia in 20181
}

\begin{abstract}
The aim of the article is to determine the type of activities undertaken by the Catholic Church towards clergymen committing sexual offenses, and more specifically: pedophilia. The research problem is a question: what actions does the Catholic Church take against pedophilia? In order to realize a research project, it was first determined how the offense is defined in the doctrine of church criminal law. Then, there was made an analysis of the activities undertaken by the hierarchs of the Catholic Church. On its basis, a typology of the forms of the Church's influence at various levels was reconstructed in the field of both preventive and sanctioning actions against the clergy. In the article there was adopted a time restriction covering only 2018. It can be described as a breakthrough, first of all due to the verdict that was made in Poznan (MS, 2018), the accusations that appeared at the end of the year against the deceased chaplain of Solidarity, Fr. Henryk Jankowski and initiatives taken by both citizens and politicians, such as the first anti-clerical happening of Baby Shoes Remember in Poland or the creation of a pedophile map. In the cinemas, a movie entitled "Kler" showed up. It moved the topic of pedophilia in the Church. Results: the Catholic Church in Poland, apart from symbolic activities, i.e. oral and written declarations, assurances, and prayers, undertakes also substantial actions, such as personal changes, cooperation with the state or the meetings of hierarchs centered around pedophilia.
\end{abstract}

Keywords: The Catholic Church, pedophilia, types of activities against pedophilia, sexual offenses

\section{Introduction}

The aim of the article is to determine the type of actions taken by the Catholic Church towards clergymen committing sexual offenses. The research problem is therefore the question: what actions does the Catholic Church take against pedophilia? The article adopted a time restriction covering only 2018. It can be described as a breakthrough, first of all due

\footnotetext{
${ }^{1}$ It should be noted that the article was written in 2018.
} 
to a judgment passed in Poznań, which concerned the payment by the Christ's Society of a million zlotys of compensation and PLN 800 a monthly annuity for a spiritual sacrifice belonging to this congregation (MS, 2018). This verdict sets a precedent in the country, because for the first time the Church in Poland was held liable (MS, 2018). Another issue concerns the accusations that appeared at the end of the year against the deceased chaplain of Solidarity, Fr. Henryk Jankowski (Socha, 2018). This is a breakthrough year also due to initiatives taken both by citizens and politicians, such as: the first anti-clerical happening in Poland for Baby Shoes Remember (Dziecięce buty na płotach..., 2018), or creating a pedophile map (Diduszko-Zyglewska, Scheuring-Wielgus, Lisiński, Nowak, 2018). In the cinemas, a movie entitled "Kler" showed up. It moved the topic of pedophilia in the Church. In order to realize this research project, it was first determined how the offense is defined in the doctrine of church criminal law. Then there was made an analysis of the activities undertaken by the hierarchs of the Catholic Church (including, for example, argumentation). On its basis, a typology of forms of the Church's influence at various levels was created in the field of both preventive and sanctioning actions against the clergy. The organizational structure of the Roman Catholic Church in Poland is as follows: Holy See, Bishops' Conference, metropolis, diocese, deanery, parish. However, in the case of this article, I make some simplification - I focus especially on the Holy See and the Bishops' Conference. Thanks to such a procedure it is possible to create a typology of the most representative and binding examples of activities undertaken by the Catholic Church, without unnecessary, in this case, shredding.

\section{The Theoretical Background of Reflections on Pedophilia in the Catholic Church}

There are many publications regarding the problem of pedophilia in the Church, including the ones written by Polish authors, though these authors were writing very carefuly and skeptically. Typically, this issue is considered by researchers in the context of media coverage about it (Kloch, Przybysz, 2014; Szczepański, 2014; Różycki, 2010) on the example of other countries, including Germany (Kycia,2011). In the case of other texts, hypotheses and research problems are missing, they are rather subjective descriptions of facts (Szul, 2015) or rather cursory comparative analyses of the activities undertaken by the Holy See during the pontificate of three different popes (Suchocka, 2015). Nowadays, the topic is recognized as a priority and requiring diligent studies. There is a clear increase in the numer of publications concerning the problem of pedophilia in the Catholic Church (e.g. Żak, Kusz, 2018; Żak, 2019). On the streets of Polish cities one can find advertisements of foreign sociologist's book Sodoma. Hipokryzja $i$ władza $w$ Watykanie, which undertakes the issue of homosexualism in the Cathloic Church throughout the world.

An article deserving of attention, despite the distant date of publication is the text by Norbert Rigali (Rigali, 1994). He also indicated what actions the Church undertook regarding 
the phenomenon of pedophilia on the example of Canada and the United States. Among them, he mentioned the guidelines of the Canadian bishops, the establishment of an inquiry commission by the archdiocese for accusations referring to priests, and a year later a report on them, the establishment of an ad hoc Committee on Child Sexual Abuse. The committee issued, among others, the From Pain to Hope report, whose last chapter contained fifty recommendations, this time referring to the whole Church, and not only to the Canadian bishops. The groups of people to whom they are directed are defined. A small number of activities were mentioned and proposed, for example, bishops were instructed to appoint a delegate and deputy delegate in dioceses, and to establish a special advisory committee of at least five people (Rigali 1994). Moving to the United States, the activities that can be distinguished on the basis of Rigali's article are plenary meetings, during which there were discussions on the problem of pedophilia; public statement episcopal conference, which, as the author specifies, was rather damage-control press release, rather than the message of the pastor; public apologies of Archbishop Daniel Pilarczyk and detailed recommendations for all dioceses (More: Rigali 1994). Another activity that was undertaken was the report of the Chicago commission to Joseph Cardinal Bernardin. It is worth noting that, as the author pointed out in addition to the soon-mentioned From Pain to Hope report, individual dioceses also published their own statement about the sexual abuse of minorities by priests. All this, however, was the result of formulated general recommendations, hence they have many common features. The other types of activities are reports and consultations of the cardinal with archdiocesan advisory bodies and political statements. The last extremely important activity undertaken by the Church was the publication of the letter of John Paul II during the meeting of the Episcopate Conference which also provided a hint about the procedure of suspending and firing clerics. The letter also referred to the establishment of a joint committee of the Holy See and the bishops conference."The conference also received at its meeting, for review by the new ad hoc committee, the recommendations of a think tank on the sexual abuse of children that had been convened a few months earlier by the NCCB Priestly Life and Ministry Committee" (Rigali, 1994).

\section{Crime in the Doctrine of Church Criminal Law}

One can assume, just like Małgorzata Bryła, that the concept of crime in the legal and canonical categories "should be understood as an external violation of a law or order seriously accounted for as a result of intentional and unintentional guilt" (Bryła, 2005). In order to be able to describe a given act as a crime, three conditions must be met: public damage was caused by the external legal order, the violation was caused intentionally and the violated legal norm involves legal sanctions. The types of penalties provided for are censorship, expiation, punitive and penal measures (Bryła, 2005). Importantly, the application of the abovementioned penalties is treated as a last resort. As for Kan. 1341, quoted by Małgorzata Bryła, "the Ordinary only then should initiate legal or administrative proceedings to impose 
or declare punishment, when he acknowledges that neither fraternal correction nor reprimand, nor other means of pastoral care can be sufficient to repair scandal, compensate for violated justice and lead to to improve the guilty party" (Bryła, 2005). In a similar vein, in an interview for Niedziela, Fr. Dr. Jarosław Kośla, who is an official of the Warsaw Metropolitan Court, "it is true that for the decree of punishment, it is important to know about the circumstances of committing a prohibited act. In the case in which canon law applies, learning about the circumstances of a crime - such as, for example, motivations and the perpetrators' awareness - seems to be even more important than in the trial before a secular court. Mainly because the overriding principle of the Catholic Church is the salvation of souls. This means that the Church's imposition of punishment is not a retaliation or isolation, as in secular law. The aim of canonical criminal law is to come with the help of a man so that he can achieve salvation" (Interview with Jarosław Kośla, 2011). Krzysztof Mikołajczuk in his article on the concept and purpose of punishment in the Church, in historical and legal terms, also sees that punishment by the Church is the final measure, after exhausting measures such as "teaching God's Word, administering the sacraments, encouragement, persuasion, father's admonition disciplinary acts" (Mikołajczuk, 2016, p. 102). Another issue is the mystery of confession, which applies to clergy, and reporting a crime such as pedophilia to state organs, which can lead to the loss of trust on the part of the faithful to the sacrament of confession. In view of this dilemma, Bishop Dydycz, in a pastoral letter from 2013, stated that “(...) the Canon Law provides enough sanctions. It is enough to reach for them, use them. Let us use them. On the other hand, the secular authorities should guard people's safety in accordance with civil law" (Dydycz, 2013). In the further part of the work, however, I attempt to create a typology of actual actions undertaken by the Catholic Church and compare it with the declared attitude of the hierarchy of this institution to pedophilia. This seems more justified than the use of solutions and penalties provided in canonical law in the light of the above statements and the Church's attitude to the application of penalties.

\section{Hierarchy Statements about Pedophilia}

The problem of pedophilia in the Church has been known for a long time, but one can get the impression that in recent times the message about it has been intensified. Both thanks to the media, politicians, confessions of public figures, and more and more new confesions from the victims of pedophile priests (I am referring to mass media issues because it is still difficult to estimate the scale of the problem at local and national level, and also considering the percentage of people who did not report a crime). A few years ago, the United Nations also vocalized its opinion, demanding that the Church removes priests who have committed or are suspected of committing crime; reports crimes to the police; makes available Vatican archives relating to pedophilia and the issue of covering up the problem and the responsibility of the superiors in this regard. In addition, a postulate was proposed to revise the Church's teaching regarding contraception, abortion and homosexuality (Bielecki, 2014). Pedophilia 
in the church has also become one of the topics raised in the speeches during the meeting of the synod of bishops about the youth taking place in the Vatican. The President of the German Episcopal Conference Cardinal Reinhard Marx stated that “(...) First, the church must show that it is a safe place for children. Secondly, young people want the Church to be an open, transparent and inclusive community" (adso, 2018). He also assured that the Holy See will present explanations regarding the former Archbishop of Washington and former Cardinal Theodore McCarrick (adso, 2018). In turn, Pope Francis, after publishing a report on sexual crimes committed by clergy in America, in a letter addressed to the faithful around the world, stated that "the size and seriousness of events requires dealing with this fact in a global and communal way. (...) Today, as God's people, we are called to take responsibility for the pain of our brothers, wounded in body and soul. If in the past negativity could become a way of reaction, today we want solidarity, understood in its deepest and demanding sense, to become our way of creating a present and future history in an environment where victims of conflicts, tensions, and especially abuses of all kinds could find a helping hand that would protect them and free them from pain. Such solidarity requires us in turn to disclose everything that may threaten the integrity of each person" (Pope Francis, 2018, pp. 7-9). This statement can be treated as another declaration of greater transparency on the part of the Church and non-compliance with the responsibility for criminal offenses. On the other hand, in Ireland, the Pope prayed for victims and forgiveness from God, and he said that " $(. .$.$) this open wound calls us to call us to be firm and determined in search of truth$ and justice" (mch: Pope Francis, 2018). The Pope also announced, "Let it be clear that in the face of these abominations, the Church will spare no effort to do everything in its power to bring justice to anyone who has committed such crimes. The Church will never try to hide or downplay any case" (Pope Francis in: $\mathrm{mm}$ 2018). Despite the scale of the problem, the Holy See refers to the issue of pedophilia in a sparing way, but does not evade the responsibility of the Church. More statements and declarations are made by the hierarchs of the Catholic Church in Poland. The result of the $380^{\text {th }}$ Meeting of the Plenary Conference of the Polish Episcopate was, among others, the decision to create statistics on pedophilia in all Polish dioceses and the announcement of the creation of a program to protect minors against abuse, as well as to develop a document on preventive measures (Conference of the Polish Episcopate, 2018). As declared by the hierarchs, "Children and young people are a constant concern of the Church, which requires, among others, actions to protect minors against abuse. The standpoint in this matter is still valid and unchangeable: zero tolerance for sin and the crime of pedophilia in the Church and in society" (Conference of the Polish Episcopate, 2018). They further declared that “(...) rules for reacting to evil were developed. Reliable notifications are included in the preliminary investigation and their results are passed to the Vatican Congregation for the Doctrine of the Faith. Proceedings in this matter are also in accordance with the applicable state law" (Conference of the Polish Episcopate, 2018).

The conference of the Polish Episcopate as the main organ of the Church in Poland must present an unambiguous position in every matter. However, in the past the hierarchs were 
presenting divergent positions on the problem of pedophilia, starting from a conservative one and ending with those that aroused great controversies both in public opinion and other clergy. Currently, there have been few statements from the Catholic Church in Poland and they have been largely consistent. This year, emotions were accompanied primarily by the sentence for the amount of one million zlotys, which was mentioned earlier and the subsequent cases, which still procede in the courts. Here one can quote one of the most popular statement by Bishop Pieronek, who in an interview with Monika Olejnik stated "from the legal point of view the Church as a community has no obligation to pay for other people's sins" (Pieronek, quoted in tvn24, 2018). However, a much more important statement from the point of view of this article is the one that Bishop Czaja wrote to his faithful, especially if we put it together with the sooner mentioned statement of Bishop Dydycz from 2013. This hierarch announced that in the diocese of Opole, "three of our priests have already heard the final verdict. One was expelled from the priesthood and his trial was pending in the state court, two were sentenced by a valid sentence to imprisonment, one suspended and the other executed in prison. The fourth sentence is not yet final. The proceedings ordered by the Congregation for the Doctrine of the Faith are in progress in relation to these three. With regard to two others, guilt has been prescribed, but the Congregation has imposed penance" (Czaja, 2018). He continued, in the same tone, "therefore, in the situation of reporting the possibility of committing a crime, there can be no other option, such as zero tolerance for the offender and full support for the victim and the immediate family. I mean professional psychological and spiritual as well as legal help" (Czaja, 2018). In addition, he encouraged the victims of crime to contact the Delegate for the Protection of Children and Youth, to conduct preliminary proceedings, after which the case is submitted to the Congregation for Doctrine and Faith and state law enforcement agencies and the obligation to report to the prosecutor's office any person who knows about the sexual absue. Czaja also mentioned the prevention program, which was the subject of the $380^{\text {th }}$ Meeting of the Polish Episcopate Plenary Conference and the establishing of the priest's functioning rules, who was convicted by a valid criminal verdict which was not yet decided by the Holy See. Finally, Czaja encouraged all priests to participate in the penitential service (Czaja, 2018). Archbishop Wojciech Polak also spoke about the subject of pedophilia in the Church, but he did not refer to the specific forms of action, but rather referred to the findings of the Polish Episcopate Conference and assured that actions and the fight against pedophilia will be taken (Polak, 2018).

\section{Actions of the Catholic Church Against Pedophilia in 2018}

In this part of the article one should start with a statement by Jan Hartman, who said that "under the influence of massive pressure around the world, the Church has come a long way from a shameful policy of hiding pedophiles or crowding out the mass and systemic character of church pedophilia up to forced, nonetheless, effective cooperation with law 
enforcement agencies. It can be assumed that we were at the moment when the Vatican's apologies are no longer just speech-grass, but foretell real actions" (Hartman, 2018). This statement is quite optimistic and shows that the efforts undertaken by the Catholic Church to fight with pedophilia become clearer than the declarations made so far. Especially, because in the survey conducted on September 18-19, 2018 by SW Research for the rp.pl website "Do the hierarchs adequately deal with the problem of pedophilia among clerics?", $72.6 \%$ of the respondents answered "no" (Szaniawski, 2018). It certainly does not have a positive impact on the image of the Church and its perception, so it is worth to analyze the actions actually taken to counteract pedophilia. It would be necessary to start from praying, which is an activity surprisingly often omitted by many people, and which is extremely important if we consider it from the point of view of a Catholic or even Christianity itself and its doctrine of forgiveness. The editors of the DEON portal, one of the most popular religious portals in cooperation with the Jesuit Prayer on the Way, in October, especially encouraged to pray in four intentions, including for victims of sexual abuse, priests, people shocked by the scandals and for all the faithful. It is also an expression of compliance with the Pope's call for common prayer (Editorial DEON.pl, Prayer on the Way, 2018). The same message was made public on the portal by the editors of the Catholic Information Agency, in which the hierarchs of the Catholic Church in Poland sit on the programme council (KAI, 2018). Another form of reference by the Church to the problem of pedophilia was to raise this issue in the final document approved by the Pope, resulting from the XV assembly of the ordinary Synod of Bishops on Youth, faith and discernment of the vocation. This was a fragment referring to all kinds of abuse, and the Synod called in it "to resolutely implement measures to prevent such abuses and eradicate all forms of them, from the selection and formation of those who will be entrusted with responsible and educational tasks" (kg, KAI, vaticannews, mip, 2018). Another type of action taken is expulsion from the priesthood, as in the case of two Chilean bishops expelled by Pope Francis (kg, 2018). This is onsistent with what he had already announced in 2016 in the pastoral letter «motu proprio 'Come una madre amorevole'» in which he made mentions, among others, on new norms regarding the removal of bishops from office (Pope Francis: $\mathrm{mg}, 2016)$. It happens, however, that the clerics themselves resign from the office, such as the Washington metropolitan, or Cardinal Wuerl, or his predecessor, Theodore McCarrick (adso 2018). In the case of the former, one can also speak of the form of action which is an oral apology, in this case for "possible past mistakes in the assessment" (momo, rzw, 2018). The next step that was taken in the matter of pedophilia is called by Francis for February 2019 a three-day summit with the chairmen of episcopates from around the world, regarding sexual abuses (mtom, 2018). In connection with this summit, in response to an appeal from the organizers, Archbishop Stanisław Gądecki will meet with victims of abuse before the February meeting, but privately not publicly (Kozłowski, 2018). Another strategy was taken by the bishop of the Polish Army, Józef Guzdek, who published data on sexual harassment by military chaplains in previous years (Zubrzycki, 2018). 


\section{Classification of the Activities of the Catholic Church}

On the basis of the above-mentioned statements and undertaken activities, one can try to create a classification of the Catholic Church's activities towards pedophilia in 2018. However, one should be aware that this is only a small part because of the time limit imposed. Its legitimacy results from the fact that so far, no action has been taken on such a scale in connection with pedophilia, both on the part of politicians, citizens and the Church itself. In addition, for the first time the Church was held liable for committing the offense by one of the clergies. It is also the creation of a map of pedophilia, which has not existed so far, and now to a certain extent it allows to illustrate the situation in the Polish Catholic Church. This problem can be considered from a several-year perspective, which would allow for a more general outline, as well as an analysis of changes, intensification of actions or omissions, but this is not the research goal of this article. In this article, as it was indicated at the beginning, I do not refer to the provisions of canon law, but rather to what steps are actually taken by the Catholic Church, especially in 2018. In order to facilitate the understanding of the issue, the proposal for the classification of activities has been included in the table No. 1 in the bibliography. The types of activities undertaken by the Church can be divided into five types: oral, written, personal changes, state-church cooperation and hierarchy meetings. Within the types, specific activities can be indicated. As for the oral, we have here mainly declarations of general actions as well as specific ones, e.g. the creation of statistics, a security programme or a document on preventive actions. It is also the transmission of findings, for example, synodal public opinion, during press conferences and the disclosure of data on victims of sexual abuse or persons who have committed this crime. These also may be in writing. The oral category includes also apologies both on the behalf of the perpetrators and the whole Church, which were made by hierarchs, e.g. Pope Francis or Bishop Czaja in Poland. One can not ignore the prayers and the penitential services taking place, during which the faithful and clergy pray for the victims, the clergy, the people shocked by the situation in the Church, as in their own name. Another type of activity is written, in this case referring to the documents that arise both on the part of the Holy See and the Polish Episcopate Conference as well as the findings made in writing, including the statistical data mentioned before. Another type of action concerns personal changes. They can be of two kinds: either expulsion from the priesthood by the Pope or an authorized bishop, or resignation made by the clergyman himself. The type of activities, which yet in 2014 were arousing doubts of Bishop Dydycz regarding the secret of confession, is the Church's cooperation with law enforcement agencies, in other words with the state. The last type are meetings that can be divided into direct ones, which refer, for example, to the meeting of hierarchs with the victims of sexual abuses, or an audience with the Pope. Collective meetings are the name given to events such as synods or the summit planned for February 2019, both regarding sexual abuses, during which many hierarchs gather in one place of a non-private character. Another issue is that the resulting declarations, documents or appeals can be classified as oral / written. I have, 
however, decided to separate both direct and collective meetings because of their forms; the involvement of human resources and some kind of unpredictability, e.g. in the context of the summit to be held in February. Certainly, this is a large-scale event, during which extremely important issues will be raised, but until it then, its outcome remains unknown: whether it belongs to the oral, written, personal changes or the possible relations between the state and the Church types of activities against pedophilia. However, there is no doubt that a meeting itself is a breakthrough and should be treated rather as a separate form.

For the sake of clarity, in this article, which concerns the activities undertaken by the Holy See and the Polish Bishops' Conference, there were made some simplifications and generalizations based on the activities described by Norbert Rigali (Rigali, 1994), because within the guidelines and recommendations described by the author a number of minor activities were mentioned and suggested, referring to specific states, which were not relevant from the point of this article; also, there were rejected those actions that were taken at the diocesan level, which is different in each country, so the author's examples could be not representative, because they refer to another countries and go beyond this article's research field. Rigali, among the activities undertaken by the Church, indicated the appointment of an inquiry commission by the archdiocese for accusations referring to priests; the establishment of an ad hoc Committee on Child Sexual Abuse for studying religious abuse or priests; plenary meetings / meeting of the episcopal conference; public apologies (of Archbishop Daniel Pilarczyk in this case); all kinds of reports, recommendations and guidelines; reports, political statements and consultations; reports of the Holy See's letters; and the issue of suspending and firing clerics on the occasion of the letter; establishing a joint committee of the Holy See and the bishops conference. It is clearly visible that the activities described by me to a large extent coincide with those indicated by Norbert Rigali but also complement each other. In this way, guidelines, recommendations, reports, statements or letters can be classified in my case as: written, and as the results of meetings; the oral category can be attributed to the apology of the archbishop; plenary meetings / meeting of the episcopal conference to the category of collective meetings; and for example, the consultations mentioned by the author, to the type of face-to-face (direct) meetings. Within my typology there was nothing like the ad hoc Committee on Child Sexual Abuse indicated by the author, or a committee of inquiry (Rigali, 1994). The attention should be paid also to the fact that - what in my case was classified into oral categories, i.e. all kinds of declarations of action, such as the implementation of prevention programmes - in the American example was already signaled years ago.

\section{Summary}

Sexual abuse is a very delicate and extremely difficult issue. Every time a child or a disabled person becomes a victim, the more opposition and anger we feel towards the offender. The matter becomes even more complicated when a clergyman is accused. A man who exercises the profession of social trust that is and should be close to people on a daily basis. Debates on 
counteracting this type of abuse have been going on for years, but even now we hear about new so-called pedophile scandals. I intentionally avoid the subjective assessment of the activities undertaken by the Church, since a diligent scientific article should not contain them. That is why the research problem was formulated in such a way to be a question: what actions does the Catholic Church take against pedophilia? Formulated like that it focuses on actual activities and the analysis of speeches, not their assessments. Due to the article's timeframe the year 2018 was quite special because of the verdict that was made in Poznań, the first of its kind, in which the Church's civil liability was discussed. It was a December issue when the charges were brought against the deceased chaplain of Solidarity, Fr. Henryk Jankowski or initiatives taken both by politicians and citizens, having in mind the anti-clerical happening of Baby Shoes Remember or creating a map of pedophilia, minor urban parades, and Kler release. The subject becomes even more interesting when we hear accusations against the Church that it does not undertake any preventive actions and that it does not hold responsibility for the clergy, including financial and compensational one. The research hypothesis that was verified was: The Catholic Church undertakes actions of both substantial and symbolic nature against pedophilia. For this reason, the research goal, that was set in this article, was to determine the type of activities undertaken by the Catholic Church towards clergymen committing offenses. The analysis made it possible to distinguish several types of activities and clearly indicated that the Church not only speaks but also undertakes various activities to help victims, prevent further offenses, and apply penalties to people who have already done the harm. Holding responsibility manifested by the apologies, requests for forgiveness and the willingness to intensify the efforts to fight with pedophilia in the global dimension becomes increasingly more pronounced. The symptoms of changes seem to be the summit on pedophilia summoned by the Pope, which will take place in February 2019.

\section{References}

adso. (2018). Kardynał Marx: synod w Watykanie porusza sprawę pedofilii, Retrieved from: https://www.tvn24. pl/wiadomosci-ze-swiata,2/kardynal-marx-synod-w-watykanie-porusza-sprawe-pedofilii,873795.html adso. (2018). Pokłosie raportu o pedofilii. Papież przyjął rezygnację metropolity Waszyngtonu, Retrieved from: https://www.tvn24.pl/wiadomosci-ze-swiata,2/papiez-przyjal-rezygnacje-metropolity-waszyngtonu, 875583. html.

Bielecki, T. (2014). Czego ONZ domaga się od Kościoła w sprawie pedofilii? Pokażcie archiwa, rozliczcie biskupów [Analiza], Retrieved from: http://wyborcza.pl/1,75968,15403210,Czego_ONZ_domaga_sie_ od_Kosciola_w_sprawie_pedofilii_.html

Bryła, M. (2005). Kary w Kościelnym prawie karnym, Retrieved from: http://www.kosciol.pl/article. php/20050430222401341

Czaja, A. (2018). Bp Czaja napisał poruszający list do wiernych swojej diecezji. Ujawnił nadużycia seksualne księży, Retrieved from: https://www.deon.pl/religia/kosciol-i-swiat/z-zycia-kosciola/art,35915,bp-czajanapisal-poruszajacy-list-do-wiernych-swojej-diecezji-ujawnil-naduzycia-seksualne-ksiezy.html

Diduszko-Zyglewska, A., Scheuring-Wielgus, J., Lisiński, M., Nowak, A. (2018). Mapa kościelnej pedofilii w Polsce, Retrieved from: http://nielekajciesie.org.pl/news75-Mapa_koscielnej_pedofili_w_Polsce 
Dydycz, A. (2013). Bp Dydycz o tajemnicy spowiedzi, grzechu i donosicielstwie, Retrieved from: http:// niedziela.pl/artykul/6581/Bp-Dydycz-o-tajemnicy-spowiedzi-grzechu-i/

Dziecięce buty na płotach kościołów w całej Polsce. To akcja przeciw pedofilii.(2018). Retrieved from: https:// www.wprost.pl/kraj/10148492/dzieciece-buty-na-plotach-kosciolow-w-calej-polsce-to-akcja-przeciwpedofilii.html

Francis. (2018). translated by: L’Osservatore Romano, wyd. polskie, 8-9 2018, pp. 7-9.

Francis: mg/mg. (2016). List Apostolski «Motu proprio ‘Come una madre amorevole», Retreived from: https:// opoka.org.pl/biblioteka/W/WP/franciszek_i/motu/come_una_madre_04062016.html

Francis: mch. (2018). Papież Franciszek o pedofilii w Kościele: Błagam Pana o przebaczenie za te grzechy, Retrieved from: https://www.rmf24.pl/fakty/swiat/news-papiez-franciszek-o-pedofilii-w-koscieleblagam-pana-o-przeb,nId,2623224

Francis: mm. (2018). Papież: Kościół przekaże sprawców pedofilii wymiarowi sprawiedliwości, Retrieved from: https://www.tvn24.pl/wiadomosci-ze-swiata,2/pedofilia-w-kosciele-papiez-kosciol-nic-nie-bedzieukrywal,894268.html

Hartman, J. (2018). Papież Franciszek zapowiada walkę z pedofilią w Kościele, Retrieved from: https://www. polityka.pl/tygodnikpolityka/swiat/1760856,1,papiez-franciszek-zapowiada-walke-z-pedofilia-w-kosciele.read

KAI. (2018). DEON zachęca do modlitwy za ofiary nadużyć seksualnych, Retrieved from: https://ekai.pl/ deon-zacheca-do-modlitwy-za-ofiary-naduzyc-seksualnych/?fbclid=IwAR0uYfRGb54qG6mzq9RkW y4Bkvvhjf3wf7vz2x5kPN6wTz6nzhbCKArC_rY

kg, KAI, vaticannews, mip. (2018). Zakończył się Synod o młodzieży. Papież przyjął dokument końcowy, Retrieved from: https://ekai.pl/zakonczyl-sie-synod-o-mlodziezy-papiez-przyjal-dokument-koncowy/

kg. (2018). Papież wydalił ze stanu kapłańskiego dwóch biskupów. Episkopat przeprasza za ich czyny, Retrieved from: https://www.tvn24.pl/wiadomosci-ze-swiata,2/chile-papiez-wydalil-ze-stanu-kaplanskiego-dwochbiskupow,875919.html?fbclid=IwAR1azwGPG6G2z3EinDIDE8P4bPnCeNdVFJ9fZoydSespXL7JXRv aCzVkr8A

Kloch, J., Przybysz, M. (2014). Medialny przekaz problematyki pedofilii w Kościele katolickim w Polsce. Sympozjum, No. 2, pp. 93-112.

Conference of the Polish Episcopate. (2018). Komunikat z 380. Zebrania Plenarnego Konferencji Episkopatu Polski, Retrieved from: https://episkopat.pl/komunikat-z-obrad-biskupow-duszpasterstwo-mlodziezyi-rodzin-oraz-zdecydowane-przeciwdzialanie-naduzyciom-2/

Konferencja Episkopatu Polski. (2019). Biskupi do wiernych: nie uczyniliśmy wszystkiego, aby zapobiec krzywdom, https://episkopat.pl/biskupi-do-wiernych-nie-uczynilismy-wszystkiego-aby-zapobiec-krzywdom/

Kozłowski, M. (2018). Jest reakcja na apel Watykanu. Abp Stanisław Gądecki spotka się z ofiarami księży pedofilów, Retrieved from: http://wiadomosci.gazeta.pl/wiadomosci/7,114883,24301560,jest-reakcjana-apel-watykanu-arcybiskup-stanislaw-gadecki.html

Kycia, T. (2011). Kościół wobec pedofilii - doświadczenie niemieckie. Więź, No. 634-635, pp. 36-43.

Martel, F. (2019). Sodoma. Hipokryzja i władza w Watykanie. Warsaw: Wydawnictwo Agora.

momo/rzw. (2018). Kardynał miał tuszować przypadki pedofilii. Przeprosił za "ewentualne błędy”, Retrieved from: https://www.tvn24.pl/wiadomosci-ze-swiata,2/kardynal-wuerl-przeprosil-za-bledy-z-przeszlosci, $875672 . h t m l$

Mikołajczuk, K. (2016). Pojęcie i cel kary w Kościele. Rys historyczno-prawny. Studia Prawnicze KUL, No. 1(65).

MS. (2018). Kościół wypłacił jednak milion złotych ofierze księdza pedofila, Retrieved from: https://www. newsweek.pl/polska/spoleczenstwo/kosciol-zaplaci-milion-ofierze-ksiedza-pedofila-sad-utrzymalwyrok/plcgxyq 
mtom. (2018). Papież wzywa biskupów z całego świata. Tematem pedofilia w Kościele, Retrieved from: https:// www.tvn24.pl/wiadomosci-ze-swiata,2/franciszek-zwoluje-szczyt-przewodniczacych-episkopatoww-sprawie-pedofilii,867938.html?fbclid=IwAR3qeo9u5nk1-1Sh236NMy0h68orGWBw4pmAI2xzeBGxgMZquhQOj-H3iQ4

Pieronek, T., in the interview with Olejnik M. (2018). Biskup Pieronek: Kto grzeszy ten płaci, Retrieved from: https://www.tvn24.pl/wiadomosci-z-kraju,3/kropka-nad-i-biskup-tadeusz-pieronek-o-pedofiliiw-kosciele,874509.html?fbclid=IwAR2kdVt7ZMVIuvK8skKGQWIfdz3svg0m0nRz5AZUc7DsMSfW GXQjRGgH5AA

Polak, W.: momo/adso. (2018). Prymas: Jesteśmy skazani na długą walkę. Zero tolerancji dla pedofilii w Kościele, Retrieved from: https://www.tvn24.pl/wiadomosci-z-kraju,3/prymas-polak-zero-tolerancjidla-pedofilii-w-kosciele,872760.html

Redakcja DEON.pl, Modlitwa w drodze. (2018). Intencje, o których nie wolno nam zapomnieć w październiku. Nasza odpowiedź na kryzys, Retrieved from: https://www.deon.pl/religia/duchowosc-i-wiara/grzechyzaniedbane/art,12,intencje-o-ktorych-nie-wolno-nam-zapomniec-w-pazdzierniku-nasza-odpowiedzna-kryzys.html.

Rigali, N. (1994). Church Responses to Pedophilia. Theological Studies, vol. 55, No. 1, pp. 124-139.

Różycki, S. (2010). Analiza wybranych stanowisk publicystycznych na temat tzw. pedofilii duchownych w świetle oceny prawnej. Łódzkie Studia Teologiczne, No. 1, pp. 201-216.

Socha, R. (2018). Czy ks. Henryk Jankowski stanie się symbolem pedofilii w polskim Kościele?, Retrieved from: https://www.polityka.pl/tygodnikpolityka/kraj/1774968,1,czy-ks-henryk-jankowski-stanie-siesymbolem-pedofilii-w-polskim-kosciele.read?fbclid=IwAR2jlCPUPs0CresPObqfrTMGDW6vyPcH5 mP_n0zir0izAgCLU3uUQO-6110

Suchocka, H. (2015). Działania papieży oraz Stolicy Apostolskiej na rzecz ochrony osób małoletnich. In Prawa dziecka: perspektywa Kościoła, ed. ks. Piotr Kroczek, Annales Canonici Monographiae, 3, Kraków, pp. 175-197.

Szaniawski, P. (2018). Sondaż: Czy hierarchowie radzą sobie z problemem pedofilii wśród duchownych?, Retrieved from: https://www.rp.pl/Kosciol/180929745-Sondaz-Czy-hierarchowie-radza-sobie-zproblemem-pedofilii-wsrod-duchownych.html?fbclid=IwAR16A1sIPN0tP5mCRIyt3Iegmz1TlQv6wz C75Wdj7_T7deqIpJdd-v03vj4.

Szczepański, J. (2014). Na co zachorował Kościół w Polsce jesienią AD 2013? Analizy dyskursu medialnego wokół lapsusu językowego abp. Józefa Michalika. Biuletyn Edukacji Medialnej, No. 1, pp.95-114.

Szul, J. (2015). Głos odzyskany po latach milczenia. Dziecko krzywdzone. Teoria, badania, praktyka, No. 14(1), pp. 67-79.

Interview with Jarosław Kośla (interviewed by A. Tarwid), Kara, która ratuje duszę. (2011). Retrieved from: http://www.niedziela.pl/artykul/59640/nd/Kara-ktora-ratuje-dusze

Zubrzycki, M. (2018). Krzyżak: Biskup polowy naprawdę walczy z pedofilią, Retrieved from: https://www. rp.pl/Analizy/180929912-Krzyzak-Biskup-polowy-naprawde-walczy-z-pedofilia.html

Żak, A., Kusz, E. (2018). Seksualne wykorzystywanie małoletnich w Kościele. Problem - odpowiedź Kościoła - doświadczenie polskie. Cracov: Wydawnictwo Naukowe Akademii Ignatianum.

\section{Author}

\section{Kamila Rezmer-Płotka}

kamila.rezmer@onet.pl - Nicolaus Copernicus University (Poland) 


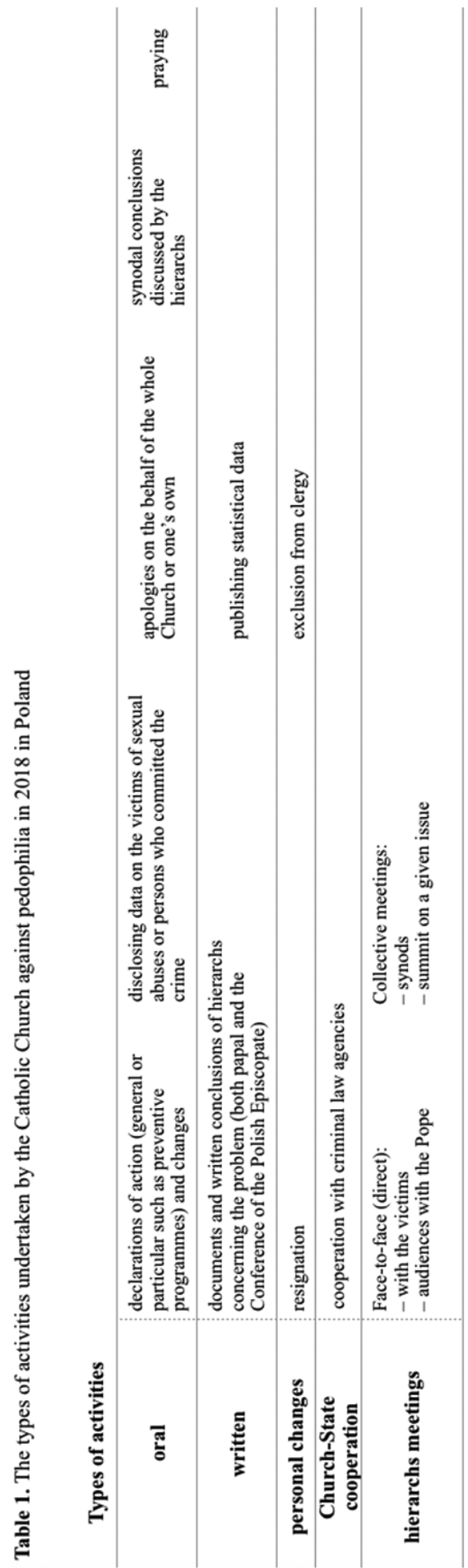


